\title{
Тува как лимитрофная зона: язык, религия и идентификация тувинцев
}

\author{
Чимиза К. Ламажаа \\ Институт социологии ФНИСЦ РАН, Российская Федерация
}

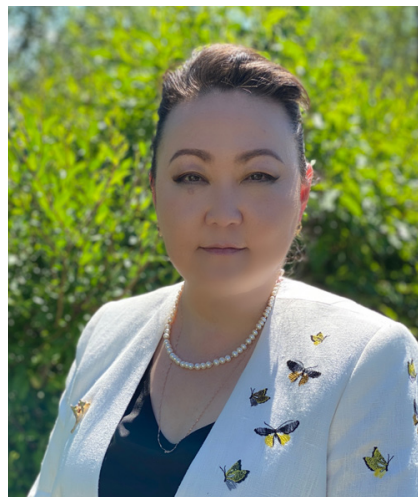

В статье Тува рассматривается как лимитрофная зона - территория, которая находится между цивилизациями, испытывает их влияние, не входит полностью ни в одно цивилизационное поле, а остается в пограничном положении. Это становится очевидным, если анализировать разные сферы социокультурной жизни региона. С одной стороны, Тува много веков развивалась как часть территории Внутренней Азии кочевников, шаманистов, буддистов. С другой стороны, она уже два века также является и частью российской цивилизации. В жизни населения в разных сферах доминируют разные цивилизационные влияния, что приводит к тяготению Тувы к разным цивилизационным общностям.

В данной статье на обширном библиографическом материале, а также данных авторских эмпирических исследований рассмотрены профессы циивилизационного влияния в сфере языков, распространенных у тувинцев - большинства населения республики, а также их религиозная приверженность и самоидентификация. В каждой из тем анализ включает историческую ретроспекцию, что позволяет увидеть исторический выбор тувинцев в том или ином вопросе, появление того или иного

фактора, его особенности.

Отмечается, что в сфере языка у тувинцев некоторое время существовал ограниченный тувинско-монгольский билингвизм, который затем сменился тувинско-русским, а сегодня имеет тенденцию к постепенной смене на русскотувинский. Российское цивилизационное влияние в сфере языка увеличивается. Тем не менее также увеличивается влияние тибето-буддийской цивилизационной общности, частью которой считают себя тувинцы-буддисты. Влияние китайской циивилиации минимально, можно говорить только о политических последствиях, к которым привела политика китайской империи. Родство с монгольской культурой у тувинцев есть, но оно ограничивается различиями языковых семей народов. Религиозные предпочтения тувинцев в свою очередь отчуждают их от других тюрков мира, большинство из которых приверженцы ислама. Эти и другие факторы также поддерживают чувство особой тувинской этнической идентичности населения.

Ключевые слова: тувинцы; Тува; лимитрофная зона; цивилизация; российская цивилизация; Внутренняя Азия; межцивилизационное взаимодействие; билингвизм; буддизм Тувы; цивилизационная идентификация

Ламажаа Чимиза Кудер-ооловна - доктор философских наук, ведущий научный сотрудник Центра политологии и политической социологии Института социологии Федерального научно-исследовательского социологического центра РАН. Адрес: 117218, Россия, г. Москва, ул. Кржижановского, д. 24/35, к. 5. Тел.: +7 (916) 413-33-85. Эл. адрес: lamazhaa@tuva.asia

LAMAZHAA, Chimiza Kuder-oolovna, Doctor of Philosophy, Leading Researcher, Center for Political Science and Political Sociology, Institute of Sociology of the Federal Center of Theoretical and Applied Sociology of the Russian Academy of Sciences. Postal address: b. 5, 24/35 Krzhizhanovskii St., Moscow, 117218, Russia. Tel.: +7 (916) 413-33-85. E-mail: lamazhaa@tuva.asia 
DIALOGUE OF CULTURES

\title{
Tuva as a limitrophe zone: language, religion and people's identity
}

Article

\author{
Chimiza K. Lamazhaa \\ Institute of Sociology, Federal Center of Theoretical and Applied Sociology RAS, Russian Federation
}

\begin{abstract}
The article sees Tuva as a limitrophe zone - that is, a territory located between civilizations, under their influence in various aspects of its sociocultural life. A limitrophe always remains a borderland and never fully becomes part of any civilizational field. This position is evident after an analysis of various aspects of the region's sociocultural life. On the one hand, for many centuries Tuva has been a part of the Buddhist, Shamanist and nomadic Inner (or Central) Asia. On the other, for the last two centuries it has also been part of the Russian civilization. In various aspects of its life, the population is dominated by different civilizational influences, which means that over a range of issues, Tuva gravitates towards different civilizational bodies.

Building on a wide range of bibliographic material, as well as data from the empirical studies made by the author, the article examines the civilizational influences in the Tuvan linguistic sphere, as well as Tuvans' religious adherence and self-identification. In each of these spheres, the analysis covers a historical retrospection shedding light on Tuvans' historical choice over a specific issue, and on the rise and development of a certain factor.

Linguistically, Tuvans have been found to have possessed a limited Tuvan-Mongolian bilingualism, later to be replaced by a TuvanRussian one. Given the generational changes, the current trend is towards the gradual rise of a Russian-Tuvan bilingualism. The linguistic influence of the Russian civilization is increasing, but also growing is the impact of the Tibetan Buddhist civilizational community which Tuvan Buddhist associate themselves with. The impact of the Chinese civilization remains minimal - unlike the political consequence the politics of the Chinese empire has led to. Tuvans also feel affinity with the Mongolian culture, but it is limited by the difference between the two languages and the language families they belong to. Tuvan religious preferences, in their turn, antagonize them from many other Turkic nations, where most people follow Islam. These and other factors contribute to the feeling of a special Tuvan ethnic identity.
\end{abstract}

Keyword: Tuvans; Tuva; limitrophe zone; civilization; Russian civilization; Inner Asia; intercivilizational exchange; bilingualism; Buddhism in Tuva; civilizational identification

For citation:
Lamazhaa Ch. K. Tuva kak limitrofnaia zona: iazyk, religiia i identifikatsiia naseleniia [Tuva as a limitrophe zone:
language, religion and people's identity]. New Research of Tuva, 2021, no. 3, pp. 178-194 (In Russ.). DOI: https://www.
doi.org/10.25178/nit.2021.3.14

\section{Введение}

Взаимодействие между цивилизационными системами можно анализировать на материале повседневной социальной и культурной жизни, которая разворачивается на пограничных территориях с населением, имеющим родственные культуры, длительную историю сосуществования и продолжающим контактировать друг с другом. Тува - одна из таких территорий. Цивилизационный подход, позволяющий анализировать не государственную принадлежность территорий, а их соотнесенность к общностям более широкого социокультурного плана - цивилизациям, дает возможность рассуждать о ней как о части территории Внутренней (или Центральной) Азии ${ }^{1}$, на которой развивалась много веков

${ }^{1}$ Географическая трактовка Центральной Азии в российской и зарубежной науке различна. В традиции советской-российской литературы Центральной Азии относятся следующие территории: Монголия; китайские регионы - Внутренняя Монголия, Синьцзян-Уйгурский автономный район, провинция Ганьсу, северная часть провинции Цинхай, значительная часть провинции Шэнси; из российских территорий - Тува, значительные территории прибайкальских регионов и Южного Алтая, то есть Саяно-Алтайский регион. Однако, в последние годы отечественные исследователи стали вслед за англоязычными коллегами использовать название «Внутренняя Азия» - Inner Asia (см. также: Гарри, 2020: 10-11). 
социокультурная общность кочевников, шаманистов, буддистов. Тем не менее, она также является и частью российской цивилизации, будучи вовлеченной в нее уже почти два века назад. Тем самым Тува выступает как одна из особых пограничных территорий, которые в современных исследованиях цивилизаций, в политической и философской науках называются разными терминами: «пограничье», «трансграничье», «лимитроф» («лимитрофная зона», «лимитрофная территория»), «буферная зона» и пр.

Например, в рамках исследования трансграничья России и Китая М. С. Михалев трактует место Тувы и других подобных районов как буферных зон, которые играют роль особых проводников культурных и социальных влияний между государствами (Михалев, 2018). Несмотря на то, что автор строит анализ в рамках геополитического исследования, тем не менее, можно поддержать эту мысль, анализируя и вопросы цивилизационных систем, их взаимодействия.

Сама проблематика цивилизационного взаимодействия с конца XX в. обсуждалась прежде всего с точки зрения конфликтности. Тон, как мы помним, здесь задал С. Хантингтон с концепцией «столкновения цивилизаций» (Хантингтон, 1996). Однако позднее дискуссии перестали быть столь категоричными и включали уже обсуждения разных аспектов взаимодействия, не обязательно сводящихся к конфликтам. Так, Й. Арнасон предложил обратить внимание на более фундаментальный вопрос в проблематике межцивилизационного взаимодействия, в которой важны контакты разных уровней и трансмиссия важнейших культурных ресурсов (Арнасон, 2015). В. Л. Цымбурский также писал о том, что цивилизационная геополитика, которая стремится быть продуктивной, не должна замыкаться на догме «столкновения цивилизаций» (Цымбурский, 2000: 58).

Поддерживая расширенный подход к межцивилизационному взаимодействию, я обращусь к анализу социокультурной жизни территории, продолжая также дискуссию, начатую М. С. Михалевым относительно возможности применения социокультурного подхода (когда акцент делается на изучении особенностей культуры, социальной организации, характера и идентичности жителей, см.: Михалев, 2018: 124), а также Ю. В. Попковым и Е. А. Тюгашевым - об особенностях пространственного развития Тувы как лимитрофа (Попков, Тюгашев, 2019).

Для анализа особенностей межцивилизационного взаимодействия я сначала обосную положение Тувы как лимитрофной зоны, затем проанализирую те социокультурные сферы общественной жизни, в которых наиболее ярко разворачиваются процессы культурной трансмиссии - сферы языка и религии, подытоживая анализ проблематикой цивилизационной идентификации тувинцев.

В качестве источниковой базы исследования выступят материалы научных публикаций, социологических исследований последних лет (2000-2021 гг.), опубликованных разными авторами, а также тех, в проведении которых я принимала непосредственное участие; материалы моих наблюдений в Туве.

\section{Тува как лимитрофная зона}

В литературе, посвященной проблемам межцивилизационного взаимодействия разных регионов мира, объекты исследования делятся на «макрообъекты» (метацивилизации, цивилизации), «мезообъекты» (лимитрофы, пограничные территории, небольшие государства) и «микрообъекты» (части государств и цивилизаций, отдельные регионы, лимитрофные зоны). Последние в силу своей незначительности в цивилизационных теориях учитываются мало, лишь порой приводятся в качестве примеров отдельных пограничных территорий. Но внимание к подобным объектам, на мой взгляд, не менее важно, поскольку позволяет увидеть сложность и пестроту цивилизационной картины мира, а также конкретизировать вопросы взаимодействия больших цивилизационных систем.

Территория Тувы за многовековую историю существования в древности и средневековье входила в состав разных кочевых империй, находясь практически всегда в их периферии ${ }^{1}$. B XIII в. вошла в состав Монгольского государства Чингисхана, его потомков, затем была частью монгольских государств. B XVII в. Россия начала распространять свое влияние на территорию южной Сибири, в том числе Тувы (Дацышен, 2005: 46-55), однако затем Китай утвердился в притязаниях на Саяны «под предлогом

${ }^{1}$ Это, однако, не означало, что тувинцы не принимали ничего для сохранения своих интересов, например, в XVII в., используя для этого также борьбу между крупными государствами в регионе (см.: Дацышен, 2005: 30). Та же стратегия помогла им и в начале XX в. на короткий исторический срок провозгласить и собственную государственность - Тувинскую Народную Республику (1921-1944 гг.). 
того, что народы Южной Сибири платили дань монгольским феодалам, позднее признавшим власть маньчжурской империи» (там же: 55). Как писал В. Г. Дацышен, Пекин претендовал на власть над всеми урянхайцами, которых он относил (автор подчеркивает - безосновательно) к мятежным монголам (там же: 64), «внешним варварам» или «внешним вассалам» (там же: 65). В середине XVIII в. была установлена власть Цинской династии над Тувой.

При этом, по мнению В. Г. Дацышена, у Китая было особое отношение к Туве, которое состояло в признанной необходимости иметь стабильный регион с лояльным Китаю населением на границах с Россией и в тылу Монголии (Дацышен, 2005: 69). Территория Тувы была закрыта не только для россиян, но даже и для въезда из самого Китая (там же: 87), посещение было разрешено только цинским чиновникам (там же: 69). О том же пишет М. С. Михалев, полагая данный факт причиной того, что Тува фактически не осваивалась жителями Китая (Михалев, 2018: 126).

После заключения в 1860 г. двустороннего межгосударственного договора между Российской империей и империей Цин (Буксгевден, 1902; За три века ... , 1995: 53-60) по всей пограничной линии между ними была установлена свободная и беспошлинная торговля. «Русским было предоставлено право ездить в Китай, Монголию и Туву и свободно продавать и покупать там разного рода товары...» (История Тувы, 2001: 284). В последующем это привело к переселению русских в край, постепенному увеличению русского населения и растущему влиянию русских на тувинскую социально-политическую жизнь, что привело край к вхождению в поле российской цивилизации. Как подчеркивает С. Л. Кузьмин, в начале XX в. Урянхайский край своим считали и Россия, и Монголия, и Китай ${ }^{1}$ (Кузьмин, 2018: 4-6; см. также: Хертек, 2016). Однако, в целом Россия отстояла свое влияние на край и продолжила его укреплять.

Тем не менее, в среде тувинской политической элиты присутствовала и идея самоопределения. Нойоны продолжали лавировать в поисках варианта самосохранения тувинцев в тисках между цивилизациями. Россия им представлялась меньшим из зол, поэтому после освобождения от китайского управления в поисках внешнего покровителя они обратились на север. Революционные события в самой России позволили им на короткий срок провозгласить свою государственность, но вхождение в цивилизационное поле продолжало наращивать обороты, что привело Туву к вступлению в союзное государство.

Будучи уже в составе России Тува, несмотря на нахождение в общем поле с единой культурной политикой, тем не менее сохранила этнокультурные особенности социальной жизни. Сохранилось у нее и сложное транспортное сообщение с остальными частями страны, определяющее географическую изолированность, которая, в свою очередь, накладывает отпечаток на понимание пространства за пределами региона населением. Транспортная проблема даже выносится в важнейший пункт географической самопрезентации Тувы, как определила Н. Ю. Замятина в исследовании когнитивногеографических контекстов образов по материалам официальных региональных сайтов (Замятина, 2006: 126-127).

Географическая обособленность подкрепляется культурной обособленностью, которая очевидна как жителям самой Тувы, так и жителям остальной России. В российских масс-медиа распространено даже представление о Туве не как о части российского государства, а как об отдельном «государстве в государстве» ${ }^{2}$ Ю. В. Попков и Е. А. Тюгашев, подчеркивая, что на протяжении своей истории тувинцы вступали во взаимодействие с несколькими магистральными культурами (монгольской, китайскойманьчжурской и российской), а с российской - взаимодействие только усиливалось, тем не менее, также не видят и не предвидят здесь формирования синтетической российско-тувинской культуры (Попков, Тюгашев, 2019: 10).

${ }^{1}$ И надо сказать, что отголоски подобных представлений до сих пор присутствуют в дискурсе, например, монгольских и китайских авторов. Если от монгольских коллег я данные утверждения слышала сама в дискуссиях, то по поводу китайской точки зрения см.: Бутаков Я. «Тыва принадлежит Китаю»: почему так считают в Тайване [Электронный ресурс] // Русская семерка. URL: https://russian7.ru/post/tyva-prinadlezhit-kitayupochemu-tak-s/ (дата обращения: 06.06.2021).

${ }^{2}$ Напр.: Тыва «нероссийская» - это Сибирский Кавказ [Электронный ресурс] // ARD. 2014, 20 сентября. URL: https://asiarussia.ru/blogs/4330/ (дата обращения: 21.06.2021); Малахов М. Республика Тыва: наш маленький Тибет [Электронный ресурс] // Brodude. 2021, 23 мая. URL: https://brodude.ru/respublika-tyva-nash-malenkijtibet/ (дата обращения: 21.06.2021); Масюк Е. Что мы знаем о Тыве [Электронный ресурс] // Новая газета, 2018, 25 сентября. URL: https://novayagazeta.ru/articles/2018/09/25/77949-chto-my-znaem-o-tyve (дата обращения: 21.06.2021) и др. 
Соответственно, Тува представляется пограничной территорией, которую можно рассматривать как лимитрофную зону, входящую в Великий Лимитроф, по В. Л. Цымбурскому (Цымбурский, 2000). Причем, пример Тувы ярко демонстрирует феномен культурно-религиозной и идеологической «самообороны» лимитрофных народов Центральной Азии от ближайших цивилизаций ${ }^{1}$, о чем пишет автор концепции (там же: 78).

В рамках этой темы возникает вопрос о том, от каких цивилизаций «обороняется», например, Тува, и частью каких она является, ощущает себя.

Понимая Туву как лимитрофную зону, назовем цивилизации, влияние которых определяет социокультурную жизнь в республике и приводит к тому, что в ее разных сферах доминируют влияния разных цивилизаций. Это переплетение влияний можно также назвать межцивилизационным взаимодействием. Во-первых, безусловно мы говорим о российской цивилизации, наличие которой никем из теоретиков не подвергается сомнению. Во-вторых, в истории Тувы сыграла определенную роль и китайская цивилизация. В-третьих, необходимо сказать о самой спорной теме - цивилизации или цивилизационной общности кочевников Внутренней Азии, относительно которой мнения до сих пор различаются, порой кардинально. Одни авторы, преимущественно представители монголоведения, обосновывают идеи степной цивилизации (Буровский, 1995; Проблемы истории ..., 2000; Железняков, 2016), крупных номадных цивилизаций (Кульпин-Губайдуллин, 2008), мегацивилизационной целостности (Крадин, 1995, 2020) и др. Теоретики же или обобщали свое видение до буддийской цивилизации (Хантингтон, 1996), относили регион к дуге территории Великого Лимитрофа, к части Тибето-Синьзяно-Монгольской Центральной Азии (Цымбурский, 2000), или рассуждали в свете общей метацивилизации Востока (Хатунцев, 2011). Встречаются даже рассуждения о том, что «кочевые племена Центральной Азии - производное явление Китайской империи, ее социальное и культурное пограничье» (Кириченко, 2010: 39).

В рамках данной статьи я не буду останавливаться на разборе позиций. Это безусловно требует обсуждения общих цивилизационных схем. Лишь подчеркну, что мы не можем рассуждать о взаимодействии на рассматриваемой территории только российской и китайской цивилизаций, исключая цивилизационное своеобразие Внутренней Азии. Ряд авторов считают ее центром или ядром Монголию (Железняков, 2016) или рассматривают как ядерный локус особого монгольского мира, охватывающего в том числе и Внутреннюю Монголию Китая, и Бурятию с Калмыкией, и многочисленные монгольские диаспоры по всему миру (Монгольский мир ..., 2014: 25).

На мой взгляд, интересна в этой связи трактовка И. Р. Гарри, которая считает, что цивилизационные особенности нынешней Внутренней Азии сложились в период, когда существовало единое политическое образование монгольской империи XII-XIII вв. После этого в XIV в. она распалась на конгломерат автономных политических образований, а разграничение пространства между Российской империей и цинским Китаем означал конец свободной степи. Сейчас этот обширный регион разделен тремя государствами - Россией, Китаем и Монголией, но специфику этой безусловно культурной целостности определяет тибето-монгольский буддизм (Гарри, 2020).

\section{Билингвизм тувинцев: от тувинско-монгольского - к тувинско-русскому}

Историческая ретроспекция позволяет увидеть, как на территории Тувы с XIX в. в сфере языка происходило изменение цивилизационных влияний.

История и результаты языковой политики советского, российского государства на территории Тувы достаточно изучены филологами и историками (Монгуш, 1967; Сат, 1973; Анайбан, Губогло, Козлов, 1999: 96-99; Самдан, 2001; Бичелдей, 2010; Бавуу-Сюрюн, 2010; Цыбенова, 2013, 2019; Отрощенко, 2015; Серээдар, 2018; Боргоякова, Биткеева, 2020; Арефьев, Бахтикиреева, Синячкин, 2021 и др.), поэтому в рассуждениях я опираюсь на их заключения.

Тувинцы, не имевшие своей собственной письменности, на протяжении нескольких веков использовали в официальной и личной переписке старописьменный монгольский язык - с XVII-XVIII вв. вплоть до 1930-х гг. (Самдан, 2001; Бичелдей, 2010: 213). Более того, А. А. Самдан и И. В. Отрощенко,

\footnotetext{
${ }^{1}$ Интересно также то, что сибирский участок лимитрофа, в который входит Тува, вошел в поле внимания польских исследователей, занимавшихся проблематикой Пограничья, для сравнения с пограничьем Речи Посполитой (Цивилизационный выбор ... , 2011; Пограничье культур ..., 2012; Ламажаа, 2012).
} 
ссылаясь на наблюдения исследователей рубежа XIX-XX вв., пишут, что монгольский язык имел достаточно сильное распространение среди тувинцев и считался языком культуры, литературным языком тувинцев (Самдан, 2001: 9-11; Отрощенко, 2015: 16-17). При этом А. А. Самдан подчеркивает, что тувинцы не приспосабливали монгольскую письменность для тувинского языка, а использовали в своих нуждах монгольский литературный язык (Самдан, 2001: 9-10). То есть тувинцы не монголизировались, а в крае присутствовал билингвизм - тувинско-монгольский, и то - лишь у небольшой части населения.

Исследователи также упоминают о том, что в начале XX в. в Туве находились и книги на тибетском языке, однако они были религиозного характера, имели хождение среди священнослужителей, которые в годы культурной революции были разогнаны и репрессированы, а имущество храмов уничтожено. Китайский язык и вовсе был тувинцам недоступен в силу обособленного положения края в составе Цинской империи, о чем я уже выше упоминала.

С момента провозглашения собственной государственности - Тувинской Народной Республики, в чем тувинцам помогло советское правительство (История Тувы, 2007: 126-128), десятилетие продолжалась полемика относительно графической основы для тувинской письменности. Как справедливо расценивает И. В. Отрощенко, вопрос сразу приобрел политическую окраску и поставил тувинское государство перед цивилизационным выбором (Отрощенко, 2015: 22). Выбирая иную основу письменности, тувинцы освобождались от влияния монгольской письменности и в целом монгольского языка, переходя в поле языковой политики России.

Решающим для выбора проекта письменности в Туве исследователи называют общую российскую политику перевода на латиницу большинства языков народов СССР, которая в конце 1930-х гг. в целом была заменена на алфавит на основе русской графики. При этом один из авторитетных современных филологов Тувы К. А. Бичелдей считает, что русский алфавит «совсем не чужд для тувинского языка» (Бичелдей, 2010: 225), т. к. кириллица уже использовалась учеными (В. В. Радловым, Н. Ф. Катановым) при написании тувинских слов. Он называет выбор оправданным: «в настоящее время нет оснований бить тревогу о том, что действующая тувинская графика не справляется или плохо справляется со своей основной функцией» (там же: 226-227). Тем не менее филолог признает, что при создании тувинского алфавита был использован и политический принцип - принцип сближения к русской фонетике в русле идеи о постепенном формировании единой советской нации и единого языка (там же: 227).

Так, в 1930 г., когда было принято решение о новой основе тувинской письменности, тувинцы стали реализовывать внутреннюю политику нового правительства во главе с С. К. Токой относительно сближения с советской Россией, в том числе в плане языка, и билингвизм тувинцев достаточно быстро сменил свое содержание и из тувинско-монгольского стал - тувинско-русским.

Исторически быстрый выход тувинцев из зоны влияния монгольского языка был обусловлен не только сменой основы письменности, но и тем, что в силу разницы между языками владение монгольским было уделом лишь образованной части населения. Для основной массы тувинцев (но не для тувинцев приграничных с Монголией районов) это был язык, который даже не был понятен. Несмотря на то, что и тувинский, и монгольский языки относятся к алтайской языковой семье, тем не менее они существенно отличаются друг от друга (см.: Сат, 1996). Этот факт лежит и в основании этнической самоидентификации (о чем будет сказано далее).

В связи с вхождением Тувы в состав России, тувинско-русский билингвизм продолжал укрепляться. В итоге мы можем видеть, что, согласно данным Всероссийской переписи 2010 г., $82 \%$ тувинцев владеют русским языком и только 1,1\% - монгольским (причем еще $2 \%$ - владеют другими языками) ${ }^{1}$. Даже в приграничных районах Тувы и Монголии далеко не все знают язык друг друга - тувинцы монгольский язык, а монголы - тувинский (Ойдуп, Кылгыдай, 2012). Лишь в Эрзинском районе Тувы отмечается высокий уровень знания монгольского языка (а также высокая заинтересованность у тувинцев в этом), в силу исторических особенностей - этот район традиционно был населен тувинцами, больше контактировавшими с соседями и даже лучше владевшими монгольским языком, чем родным - тувинским.

\footnotetext{
${ }^{1}$ По данным: 7. Владение языками населением наиболее многочисленных национальностей по субъектам Российской Федерации [Электронный ресурс] // Росстат. URL: https:/gks.ru/free_doc/new_site/perepis2010/croc/ Documents/Vol4/pub-04-07.pdf (дата обращения: 21.06.2021).
} 
При том, что перепись продемонстрировала высокие показатели знания тувинцами государственного языка, тем не менее $97 \%$ указали, что владеют и родным - тувинским языком ${ }^{1}$. Правда, социолингвистические исследования у филологов вызывают тревогу относительно судьбы тувинского языка: уровень владения им падает от поколения к поколению, родной язык не считается социально престижным (Серээдар, 2018). Несбалансированная реализация государственных программ по развитию языков влияет, как считают специалисты, на лингвистическую витальность тувинского языка (Арефьев, Бахтикиреева, Синячкин, 2021: 261).

Таким образом, можно сказать, что в плане языка тувинцы не были охвачены китайским цивилизационным влиянием, а выйдя в начале XX в. из зоны влияния монгольской языковой культуры, продолжают сейчас находиться под значительным российским цивилизационным влиянием, что понятно, поскольку мы говорим о едином государственном пространстве. Тем не менее, в мультикультурном государстве внутренняя политика не столь гибка, а регион сам не уделяет достаточно внимания языковой политике по поддержке родного языка основной части населения. Это приводит к тому, что в данном случае когда тувинский язык начнет серьезно уступать русскому билингвизм тувинцев может поменять главный язык: от тувинско-русского билингвизма - к русско-тувинскому. И понятно, почему в интерактивном атласе мировых языков, находящихся в опасности, которое ведет ЮHECKO (UNESCO Interactive Atlas of the World's Languages in Danger) тувинский язык отнесен к группе Vulnerable - уязвимый ${ }^{2}$.

\section{Буддизм Тувы: от локализованной общности к глобальной}

Если говорить о языке как факторе цивилизационной идентичности, то можно вспомнить о том, что тувинский язык относится к тюркским языкам, что роднит тувинцев с другими тюркоязычными народами не только Сибири (западносибирскими татарами, якутами, долганами, тофаларами, хакасами, шорцами, чулымцами, алтайцами), но и народами Кавказа, Причерноморья, Поволжья, восточной Сибири, за пределами России - с тюрками Турции, Кипра, Сирии и др. Тувинцы улавливают мелодику, смыслы речи других тюркоязычных народов, понимают общие слова, что позволяет им ощущать языковую близость с ними. Помимо этого, один из топонимов Тувы - название города Турана, административного центра Пий-Хемского района, является одним из главных образов пантюркизма: Туран для данной идеологии - это прародина «туранских», тюркских народов, это «Великий Туран».

Эти обстоятельства позволяют некоторым идеологам включать Туву (как и другие этносы уралоалтайской языковой семьи) в регионы потенциального распространения пантюркизма (Иванова, 2012), который исходит прежде всего из Турции (Насибова, 2015). Анкара предпринимает успешные попытки по усилению своего влияния в тюркоязычных странах бывшего СССР (Гордиевский, 2007: 79), установлению регионального лидерства в регионе (Насибова, 2015: 117). Несмотря на изменения политики самой Турции с течением времени, а также изменениями мировой геополитики, как считают специалисты, эта страна вряд ли когда-нибудь полностью откажется от идеологии пантюркизма, сегодня лишь делая ставку на его смягченные варианты - «культурный неопантюркизм» (там же) или «неоосманизм» (Аватков, 2014).

Тем не менее, в России, по понятным причинам, возможности Турции влиять на культурную политику российских регионов ограничены (Иванова, 2012: 66).

Но в отношении Тувы можно указать и на иной «водораздел» между тувинцами-тюрками и другими тюрками. Этот «водораздел» - буддизм, мировая религия, которая укрепилась в Туве во второй половине XVIII в. Тувинцы-буддисты не вписываются в тюркский «идеал», в котором тюрки должны быть приверженцами ислама: «Мое имя - тюрок, моя фамилия - мусульманин» (цит. по: там же: 67).

Историография исследований буддизма в Туве также насчитывает немало интересных работ (Берзин, 1992; Монгуш, 2001; Хомушку, 2005 и мн. др.), к чему недавно также внесли лепту и мы с коллегами (Ламажаа, Бичелдей, Монгуш, 2020; Бадмаев и др., 2020; Ламажаа, Бичелдей, 2021). Помимо этого, в целом религиозная ситуация в Туве анализировалась коллегами в ряде работ (Хомушку, 2000; Монгуш,

\footnotetext{
${ }^{1}$ Там же.

${ }^{2}$ UNESCO Interactive Atlas of the World's Languages in Danger [Электронный ресурc] // UNESCO. URL: http://www. unesco.org/languages-atlas/ (дата обращения: 05.05.2021).
} 
2012, 2015, 2016; Дашковский и др., 2021). Опираясь на эту литературу, я попытаюсь сформулировать снова особенности цивилизационного взаимодействия - теперь уже на поле религиозности населения.

В данном случае интересен тот факт, что буддизм укрепился в Туве лишь с третьей «попытки»: первая волна пришлась на IX в. при уйгурах (Берзин, 1992: 24-25), вторая - на XIII в. при монголах (Монгуш, 2001: 13-17), но только третья волна (с середины XVIII в.) позволила ему не только приобрести статус официальной религии, но и быть принятой в традиции тувинцев, войдя в синтез с исконными религиозными верованиями. И закрепление третьей волны стало результатом специальной маньчжурской политики - как эффективное средство воздействия на «варварские» народы (там же: 40). Правящая династия Цин покровительствовала буддизму (причем именно традиции Гелуг) на покоренных территориях (для решения задач их управления) и это способствовало формированию в том числе его тувинского варианта (там же: 40-41). Он, как пишет М. В. Монгуш, унаследовал особенности тибето-монгольской почвы и тем самым существенно отличался от первоначального - индийского варианта (там же: 41). При этом И. Р. Гарри подчеркивает, что отличительной (от Монголии) особенностью Тувы стало распространение буддизма без подавления шаманизма (Гарри, 2020: 13).

Обычно историческая оценка завоевательской политики Китая сводится к тому, что авторы подчеркивают негативные последствия для захваченных территорий (эксплуатацию, выбивание налогов и пр.). Однако, если мы говорим о макроисторических итогах, то не стоит забывать о том, что определенная политика даже агрессоров в итоге может иметь и положительные последствия. Так, например, А. С. Железняков считает, что маньчжуры положили конец вражде северных и южных монголов, находящихся по разные стороны от пустыни Гоби (Железняков, 2016: 152). Для Тувы положительными последствиями маньчжурской политики можно назвать и утверждение буддизма, и административно территориальные реформы, позволившие в итоге тувинцам преодолеть родоплеменное деление, что впоследствии помогло укрепить общетувинскую идентичность.

Политику пропаганды буддизма целенаправленно проводили сначала главные местные правители края - амбын-нойоны, а затем подхватили кожунные правители (там же: 44). В Туву приглашались ламы из Монголии (там же: 44), сами тувинцы ездили в монгольские монастыри для обучения, а также совершали паломнические поездки для поклонения прежде всего главному иерарху монгольской буддийской церкви - Богдо гэгэну (Ламажаа, Бичелдей, 2021).

При этом, в Туве, как заключила М. В. Монгуш, темпы распространения буддизма оказались выше, чем в Монголии: ему потребовалось меньше времени, чтобы пройти путь от первых лам-миссионеров до признания его светской властью в качестве официальной религии тувинцев (в Туве это заняло чуть более полутора века, тогда как в Монголии - семь веков) (Монгуш, 2001: 54).

Буддизм в Туве довольно быстро приспособился и к соседству с шаманизмом, и с существующей политической системой, а кроме того, стал выполнять важную образовательную функцию. Развитие монастырских школ позволило дать образование населению. Это помогло сформироваться политической элите, которая сумела в начале XX в. и лавировать между империями, и выйти на путь самоопределения. Известная гибкость буддийского учения, которая дает ему возможность адаптироваться к местным обычаям и традициям (Берзин, 1992: 25-26), привела и к тому, что сами тувинцы стали считать буддизм своей традиционной религией. И, несмотря на период запрета в советское время, они этому убеждению не изменили. Даже несмотря на то, что уже к началу 1940-х гг. в Туве не насчитывалось ни одного хурээ (Монгуш, 2001: 121), все равно оставались и ламы, и верующие, которые поддерживали их, скрывали и священнослужителей, и священные реликвии, и свои убеждения. Институциональная практика была вытеснена внеинституциональной (там же: 123).

Окончание советской политики освободило религиозную жизнь, позволило тувинцам открыто считать себя верующими. Особое воодушевление население Тувы испытало в 1992 г., когда республику посетил с пастырским визитом Его Святейшество Далай-лама XIV, тогда политический и духовный лидер Тибета в изгнании (там же: 128). С этого времени тувинцы, воочию увидев иерарха своей религии, принялись восстанавливать институциональную сторону буддизма, совершать паломнические поездки в Индию, где проживает Далай-лама, а также в другие страны, где находятся буддийские святыни: Непал, китайский Тибет и, конечно же, в Монголию (Ламажаа, Бичелдей, Монгуш, 2020), тем самым осознавая себя частью большого буддийского мира (Ламажаа, 2019) и укрепляя цивилизационную идентичность с тибето-буддийской цивилизационной общностью.

Современные социологические исследования показывают, что жители Тувы идентифицируют себя по традиционным религиозным верованиям как шаманисты (5\%) или буддисты (56\%), а часто и как верующие в религиозный синкретизм шаманизма и буддизма (16\%) (Дашковский и др., 2021). Хотя 
истинно верующих, приверженцев буддийского учения очевидно меньше; буддистами большинство тувинцев являются скорее по традиции, полагая достаточным соблюдать религиозные обряды (там же: 26), не вникая особенно в суть учения (Ламажаа, Бичелдей, Монгуш, 2020: 145-146). Более того, в республике происходит очевидный процесс укрепления добуддийских воззрений, который в том числе выражается в широкой распространенности семейных, родовых, территориальных обрядов освящения местностей, объектов природы - дагылга ${ }^{1}$. Эти обряды призваны укрепить связь современных тувинцев, по их убеждениям, с духами родовых мест, духами их предков, в коммуникации с которыми им помогают обычно шаманы, но нередко обряды проводят и ламы, и старейшины аймаков (родственных объединений).

Каковы результаты, а возможно даже перспективы развития буддийского цивилизационного фактора в регионе, нам могут показать данные социологического исследования молодежи в Туве, который мы проводили с коллегами с 2019 г. (Бадмаев и др., 2020). 68,3\% респондентов (а 90\% наших опрошенных были тувинцами) назвали себя буддистами (там же: 40) и 84\% показали свое положительное отношение к нему (там же: 44). Наибольшее число респондентов - 62,1\% - считают Россию евразийским государством, объединяющим европейские и азиатские народы и культуры (там же: 41). Большинство тувинцев достаточно правильно указали на традиционные буддийские регионы страны: Туву, Бурятию и Калмыкию. А вот Монголию буддийской страной назвали лишь 51,3\% (там же: $44)$, столько же $-51 \%$ - Китай ${ }^{2} .70 \%$ респондентов считают буддизм неотъемлемой частью российской истории (там же: 42), 63\% согласны с тем, что можно говорить о российском буддизме (там же: 43 ).

Среди тувинцев есть также и приверженцы иных конфессий. Однако исследователи не делают подсчетов общего процентного числа среди тувинцев православных или протестантов. Утверждается, что таковые есть (Монгуш, 2012; Дашковский и др., 2021), но число их в соотношении с традиционалистами очень невелико.

Укорененность буддизма в республике, которая состоялась с подачи Китая и сделала Туву регионом распространения религиозного влияния и опыта «высокой» (образованной, письменной) культуры из Монголии, сблизила две подчиненные маньчжурской империи территории - Туву и Монголию. Их религиозное пространство в XIX в. стало практически общим в институциональном плане, но при этом все равно было локальной частью распространения тибетского буддизма. Однако последовавшие события разъединили организации буддистов Тувы и Монголии. На обеих территориях развернулись гонения на буддийскую церковь в результате разворачивания антирелигиозной кампании в начале советского периода (Монгуш, 2001: 120-125; Ванчикова, 2019: 77-103). В атеистических государствах - СССР, в который вошла Тува, и в Монгольской Народной Республике (1924-1992) - буддизм не был полностью под запретом, однако деятельность лам и редких монастырей была под контролем. Кроме того, и советское государство, и монгольское возлагали на буддийские организации задачи по поддержанию международных связей (Терентьев, 2014: 177: Ванчикова, 2019: 107-108).

Возрождение буддизма и там, и там началось одновременно с окончанием советской политики. В процессе возрождения тувинцы стали укреплять общность уже не с монгольским религиозным пространством, а с общим международным, центром которого является лидер тибетских буддистов (Ламажаa, 2019: 35). Соответственно, тувинцы в религиозном плане показали себя частью цивилизационного поля Внутренней Азии - той общность, которую авторы называют тибетскобуддийской цивилизацией. Разумеется, к ним также примыкают другие традиционные буддийские регионы - Бурятия и Калмыкия. Но в отношении Тувы можно сказать, что она, тяготея к тибетскобуддийской цивилизационной общности (куда входят и калмыки, и буряты, и монголы), отчуждена от монголов и локализуется в особой лимитрофной зоне тюркоязычных буддистов.

${ }^{1}$ После описания и публикации анализа одного из подобных обрядов (Ламажаа, 2021), мы с коллегами - сотрудниками лаборатории этнологии и лингвокультурологии Тувинского государственного университета за летний сезон 2021 г. собрали материалы более десяти таких обрядов из разных районов Тувы и готовим в настоящее время результаты исследования отдельным изданием.

${ }^{2}$ По результатам исследования 2019 г., данные которых хранятся у участников проекта, в том числе автора статьи. Ряд сведений, которые продемонстрировало нам исследование мнений студентов Тувинского госуниверситета, удивил нас низким уровнем знаний, элементарной осведомленности молодежи об истории буддизма в целом. Но по некоторым пунктам респонденты все же показали свое единодушие: например, в свободном перечислении стран распространения буддизма ни один из респондентов не назвал Турцию. 


\section{Цивилизационная идентификация тувинщев}

Обрисовав ситуацию на полях языковых процессов и религиозности, теперь перейдем к рассуждения о том, как сами люди - тувинцы - идентифицируют себя, в том числе в отношении к другим народам, с которыми они контактируют. Отчасти я писала об этом в своей монографии, посвященной анализу тувинского национального характера (Ламажаа, 2018: 118-134). Здесь же приведу и дополнительные сведения из публикаций, не охваченных мною ранее, а также свежих, успевших выйти за последние пару лет, подведя данный сюжет к проблематике межцивилизационных влияний.

В начале XX в. В. Родевич писал: «Ни китайцы, ни монголы не считают урянхов своими, но относятся к ним презрительно, как к низшему племени. ... Урянхи, в свою очередь, не терпят китайцев, из расовой неприязни, и как своих официальных и коммерческих эксплуататоров. Монголам сойоты издавна досаждают своими дерзкими кражами скота, и между ними также лежит взаимная нелюбовь» (Родевич, 1910: 24). Разумеется, это лишь обобщенное субъективное наблюдение, не подкрепленное ни замерами, ни опросами, но в целом оно хорошо передает истоки отчужденности тувинцев от китайцев и монголов, основанной не только на языковом непонимании.

Как писали этносоциологи, данная отчужденность привела в итоге к утверждению в среде тувинцев идеи самоопределения: «Если отдельные монгольские руководители ошибочно считали тувинцев монголами, то сами тувинцы, будучи древними тюрками по происхождению и тюркоязычными, всегда осознавали себя отдельным народом» (Анайбан, Губогло, Козлов, 1999: 18). Помощь России в этом самоопределении и сохранении своих культурных устоев стала решающим фактором для того, чтобы Тува - в период цивилизационного выбора - повернулась на север. Если до этого взаимоотношения тувинцев с русскими, которые стали активно селиться на территории края, я называла временем экономического сотрудничества и бытового общения (первая стадия взаимоотношений, см.: Ламажаa, 2018: 120-121), то затем вхождение Тувы в российские цивилизационные процессы (вторая стадия) было обусловлено сначала попыткой поиска внешнеполитического покровителя, а затем признанием советским правительством права народа на самоопределение. Несмотря на то, что в дальнейшем взаимоотношения разворачивались по модели «Старшего и Младшего брата» (третья стадия, там же: 123), тем не менее тувинская политическая элита не забывала о своей выгоде в этой модели возможности не только политической, но и всесторонней помощи со стороны северного союзника.

Надо сказать, что и Монголия была вовлечена в поле российских-советских цивилизационных процессов, воспринимая советскую модель общественного устройства и проводя в целом подобную же внутреннюю и внешнюю политику. Но она не вошла окончательно в полюс русской цивилизации. Как пишет А. С. Железняков, «процесс остановился ровно посредине» (Железняков, 2016: 165). Сам автор объясняет это эффектом самобытного «монгольского коммунизма» (там же: 166).

Возвращаясь к тувинцам, отмечу, что несмотря на вхождение Тувы официально в состав российского государства, в российскую цивилизационную орбиту, тем не менее, регион и его население сохранили положение обособленной лимитрофной зоны.

Как писала 3. В. Анайбан по итогам опроса 2006 г., 42\% тувинцев в равной мере ощущали себя представителями Республики Тыва и Российской Федерации. Но при этом $2 \%$ считали себя больше представителем РФ, а 56\% - больше представителем Тувы (Анайбан, Тюхтенева, 2008: 118-119). То есть региональная идентичность у тувинцев более ярко выражена. Но она менее значима, чем этническая, подчеркивает автор.

Результаты опроса 3. В. Анайбан показали 100\% этническую идентификацию тувинцев. Причем для подавляющего большинства этническая принадлежность «значима» или «очень значима» (там же: 119). Такое же единодушие тувинцы проявляют при определении «Родины»: «Моя Родина - республика, в которой я живу» (там же). Материалы свободного ассоциативного эксперимента с участием тувинских и русских жителей региона Э. Э. Тундума также показали большую эмоциональную окрашенность у тувинцев по отношению к Туве (красивая, родная), в отличие от размерно-пространственных характеристик, данных ими России (Тундума, 2019).

В нашем опросе молодежи Тувы 2020 г. мы выяснили, что у студентов этническая идентификация принимается половиной опрошенных тувинцев как главная. В отношении региональной и национальной (государственной) идентичностей соотношение примерно поровну (Бадмаев и др., 2020: 39). Исследование Э. Э. Тундума также показывает доминирование этнорегиональной идентичности, но без отторжения или неприятия российской идентичности (Тундума, 2019: 420).

В 1990-е годы, когда в Туве, как и по всей России, фиксировалась значительная волна этнической мобилизации, одним из важных процессов стало «удревнение» своей истории. Как писала М. В. Мон- 
гуш, наряду с этнонимом «тувинцы» в республике стал функционировать и этноним «тюрки», который с одной стороны подчеркивал идею общности происхождения тувинцев с другими тюрками, а с другой - демонстрировал этногенетическое отличие от монголов (Монгуш, 2010: 169-170). Расширение этнической идентичности у тувинцев - до азиатской, восточной, выражается также в распределении симпатий по тем или иным народам, эпохам, событиям, героическим личностям. Это, по ее мнению, приводит к восхищению у тувинцев японцами, индийцами, тибетцами, корейцами (там же: 173-175).

Азиатская солидарность у тувинцев может проявляться в ситуации, когда им важно выразить свою близость к более близким для них народам (например, во время международных спортивных соревнований, где в противоборстве сборных любой азиатской страны и российской (с русскими спортсменами) многие тувинцы будут «болеть» за азиатов), или когда они оказываются в ситуации меньшинства, как и другие азиатские диаспоры, группы в инокультурном окружении (на этом чувстве базируется активная работа тувинских и др. студенческих землячеств в российских городах).

При этом инокультурное окружение для них существует не только за пределами Тувы. Как писала еще в 1990-е гг. 3. В. Анайбан, Тува стала представлять собой регион с наиболее выраженной социальной дистанцией основных контактирующих этнических групп - тувинцев и русских (Анайбан, Губогло, Козлов, 1999: 51). Тому способствовали и различия в социально-профессиональной структуре общества, различия между городом и деревней, а также тот факт, что русские республики почти никогда не стремились и не осваивали язык большинства - тувинский язык (Анайбан, Тюхтенева, 2008: 53-54). Это приводило и до сих пор приводит к тому, что русские жители коверкают и пишут неправильно тувинские имена, названия местностей и пр. ${ }^{1}$, что может восприниматься неприязненно тувинцами.

В городской среде своей же республики тувинцы были в инокультурном окружении до тех пор, пока в 1990-е годы число русскоязычных «чужих» в Туве не стало стремительно снижаться, и в итоге тувинцы не стали большинством. Сегодня немногочисленные русские республики ощущают себя в инокультурном окружении, в том числе в условиях повсеместного использования тувинского языка, непонятного для них, в том числе в официальных мероприятиях. Как писала 3. В. Анайбан, значительное число местных русских, несмотря на достаточно длительное проживание в республике, до сих пор не в полной мере ощущают себя «тувинскими русскими» (там же: 119). Межнациональные браки в республике - не слишком популярны, как выяснила в недавнем исследовании 3. Ю. Доржу (Доржу, 2019).

Более сложную ситуацию с идентификацией тувинской молодежи замечают иностранные наблюдатели. Как пишет американская исследовательница К. Лунг, проработавшая в республике в 2015 г. и пообщавшись с тувинской молодежью, Туву нельзя считать простой провинцией, как пишут порой западные ученые; это и не бедный регион, как принято считать в остальной части России. «Это республика динамичных личностей с многочисленной мультикультурной молодежью, - считает она. Тувинская молодежь подвержена многочисленным влияниям, а не только своему кочевому прошлому. Их многогранный подход к самоидентификации проистекает из гордости русских националистов в сочетании с их собственным пониманием того, что значит быть азиатом» (Leung, 2017: 52).

Как я уже писала, единственное развернутое комплексное исследование молодежи Тувы проводилось полвека назад - в 1970-1980-х годов, когда были консолидированы усилия ученых сразу нескольких научных центров Тувы и Сибири. В 1990-е годы исследователям удалось собрать материалы о разных сторонах жизни молодежи, а также в 2000-е, когда радикально изменились и социальные условия, и сама молодежь (Ламажаа, 2015). Тем не менее, очевидно, что проблема объединения усилий для очередного комплексного исследования молодежи региона назрела и в ее решении важно учитывать проблематику сложной идентичности новых поколений тувинцев.

Приведенные показатели и мнения показывают нам, что идентификационная «карта» тувинцев имеет достаточно элементов для того, чтобы сохранялась их социокультурная отчужденность не только от жителей других российских территорий, но и от представителей русского этноса, проживающего с ними на одной территории. При этом тувинцы, сохраняя приверженность своему этносу, крепкую эмоциональную связь со своей малой Родиной, благодаря современным процессам глобализации, расширяют свою идентичность до общеазиатской, не обязательно связанной с кочевой, монгольской,

${ }^{1}$ Саяна Ондур, журналист: мужской или женский род, предлоги - основные сложности для носителей тувинского языка, изучающих русский [Электронный ресурс] // Центр Азии. 2014, 12 марта. URL: http://www.centerasia.ru/ issue/2014/10/4869-sayana-ondur-zhurnalist-muzhskoy-ili.html (дата обращения: 06.05.2021). 
буддийской. Российское цивилизационное влияние затронуло государственное строительство в регионе, экономическую и политическую жизнь, административное устройство, однако не смогло «захватить» поле идентичностей коренного населения.

\section{Заключение}

Рассмотрение языковых, религиозных и идентификационных процессов, разворачивающихся в Туве и охватывающих основную часть населения - тувинцев, позволяет увидеть, как на определенной локальной территории, в сферах социокультурной жизни происходит сложное переплетение влияний в первую очередь российской цивилизации и кочевой-монгольской, тибето-буддийской, общеазиатской социокультурных общностей. Если китайское государство в прошлом включало в свой состав Туву, определив особенности ее политического развития, тем не менее, влияние китайской цивилизации здесь оказалось минимальным. Геополитическое решение региона войти в состав российского государства, тем не менее, также не привело к нивелированию его этнокультурной специфики, оставило за ним связи с азиатскими культурными мирами, некоторые из которых могут даже укрепляться - прежде всего по религиозным основаниям. Тува с ее моноэтническим и монокультурным миром определенно тяготеет к тибето-буддийскому культурному миру или цивилизации. На этом основано положение Тувы как лимитрофной зоны.

В данной статье проанализированы сферы языка, религии и идентификации населения Тувы, однако, я полагаю, что исследование может быть расширено и углублено в том числе и на других социокультурных «полях»: праздничной культуре региона, культурных символах и образах, потребительской культуре населения и пр. На каждом из них мы можем увидеть, к чему тяготеют тувинцы, что больше считают «своим», более близким, понятным, что в их жизни позволяет говорить о том, что они часть российской цивилизационной общности, а что - нет.

Как справедливо пишет О. В. Кириченко, как бы политические державы ни ценили свою политическую монолитность, ситуация такова, что если государство имеет практически статус цивилизации, то и его центр, и приграничье (лимитрофные зоны) должны жить не по жестким политическим законам, а по гибким, каким жили всегда цивилизации (Кириченко, 2010: 34). Поэтому мне представляется, что стратегические задачи развития как российского государства в целом, так и Тувы, как одного из его регионов, должны учитывать это важное обстоятельство.

\section{СПИСОК ЛИТЕРАТУРЫ}

Аватков, В. (2014) Неоосманизм. Базовая идеологема и геостратегия Турции // Свободная мысль. № 3. С. 71-78.

Анайбан, 3. В., Губогло, М. Н., Козлов М. С. (1999) Формирование этнополитической ситуации. Т. 1. Очерки истории постсоветской Тувы. М. : ЦИМО. 420 с.

Анайбан, 3. В., Тюхтенева, С. П. (2008) Этнокультурная адаптация населения Южной Сибири (современный период). М. : б. и. 217 с.

Арефьев, А. Л., Бахтикиреева, У. М., Синячкин, В. П. (2021) Проблемы билингвизма в системе школьного языкового образования Республики Тыва // Новые исследования Тувы. № 1. C. 255-272. DOI: https://www.doi. org/10.25178/nit.2021.1.14

Арнасон, Й. (2015) Понимание межцивилизационного взаимодействия // Метод. № 5. С. 109-123.

Бавуу-Сюрюн, М. В. (2010) Тувинский язык на современном этапе: образовательный аспект // Новые исследования Тувы. No 3. С. 57-71.

Бадмаев, В. Н., Уланов, М. С., Ламажаа, Ч. К., Бичелдей, У. П., Антонов, В. И., Очирова, О. А. (2020) Россия и буддийский мир глазами молодежи Тувы, Бурятии и Калмыкии (по материалам социологического опроса) // Новые исследования Тувы. № 1. С. 35-49. DOI: https://www.doi.org/10.25178/nit.2020.1.3

Берзин, А. (1992) Тибетский буддизм: история и перспективы развития. Волгоград : б. и. 32 с.

Бичелдей, К. А. (2010) 80 лет тувинской письменности: становление, развитие, перспективы // Новые исследования Тувы. № 4. С. 210-229.

Боргоякова, Т. Г., Биткеева, А. Н. (2020) Тувинский язык в правовом и функциональном измерении // Новые исследования Тувы. № 1. С. 50-59. DOI: https://www.doi.org/10.25178/nit.2020.1.4

Буксгевден, А. О. (1902) Русский Китай : очерки дипломатических сношений России с Китаем. Порт-Артур : Издание книжного склада «Новый край». [Ч.] 1: Пекинский договор : 1860 г. 239 с.

Буровский, А. М. (1995) Степная скотоводческая цивилизация: критерии описания, анализа и сопоставления // Цивилизации. Вып. 3 / отв. ред. А. О. Чубарьян. М. : Наука. 239 с. С. 151-164. 
Гарри, И. Р. (2020) Буддизм и политика во Внутренней Азии // Oriental Studies. Т. 13. № 1. С. 8-16. DOI: https:// www.doi.org/10.22162/2619-0990-2020-47-1-8-16

Гордиевский, А. (2007) Пантюркизм без России // Россия и мусульманский мир. № 3. С. 78-80.

Ванчикова, Ц. П. (2019) Буддизм в Монголии: история, духовенство, монастыри. Иркутск : Оттиск. 292 с.

Дашковский, П. К., Шершнева, Е. А., Бичелдей, У. П., Монгуш, А. В. (2021) Религиозная ситуация в Республике Тыва (по результатам социологического исследования) // Новые исследования Тувы. № 2. C. 18-34. DOI: https:// www.doi.org/10.25178/nit.2021.2.2

Дацышен, В. Г. (2005) Саянский рубеж. Южная часть Приенисейского края и русско-тувинское отношения в 1616-1911 гг. Томск : STT. 250 с.

Доржу, 3. Ю. (2019) Межэтническое взаимодействие русских и тувинцев в советской и постсоветской Туве (на примере национально-смешанных семей) // Новые исследования Тувы. № 1. C. 144-156. DOI: https://www.doi. org/10.25178/nit.2019.1.11

Железняков, А. С. (2016) Монгольская цивилизация. История и современность. Теоретическое обоснование атласа. М. : Весь мир. 288 с.

За три века. Тувинско-русские-монгольские-китайские отношения (1616-1915) (1995) / сост. В. А. Дубровский. Кызыл : Типография Комитета по печати и массовой информации. 86 с.

Замятина, Н. Ю. (2006) Города, районы и страны в политическом рельефе российских регионов. По материалам официальных сайтов субъектов РФ // Полис. № 2. С. 122-138. DOI: https://www.doi.org/10.17976/jpps/2006.02.10

Иванова, В. В. (2012) Спелое яблоко. Идеалы пантюркизма и идентификационный синкретизм // Азия и Африка сегодня. № 1 . С. 65-71.

История Тувы (2001) / под ред. С. И. Вайнштейна и М. Х. Маннай-оола. Новосибирск : Наука. Т. 1. 367 с.

История Тувы (2007) / под ред. В. А. Ламина. Новосибирск : Наука. Т. 2. 430 с.

Киреев, А. А. (2012) К вопросу о типологии азиатских границ России (І часть) // Ойкумена. № 4. С. 37-46.

Кириченко, О.В.(2010) Российское цивилизационное пограничье // Традиции и современность. № 10. С. 34-74.

Крадин, Н. Н. (1995) Кочевничество в цивилизационном и формационном развитии // Цивилизации. Вып. 3 / отв. ред. А. О. Чубарьян. М. : Наука. 239 с. С. 164-179.

Крадин, Н. Н. (2020) Кочевники и всемирная история. СПб. : Издательство Олега Абышко. 416 с.

Кузьмин, С. Л. (2018) Урянхайский вопрос и монголо-тувинские отношения в начале XX в. // Oriental studies. Т. 37, вып. 3. С. 2-14.

Кульпин-Губайдуллин, Э. С. (2008) Спор о цивилизации // Золотоордынская цивилизация. № 1. С. 7-13.

Ламажаа, Ч. К. (2012) Концепты «За Саянами» и «тувинское время» в общественном дискурсе Тувы // Пограничье культур - культуры пограничья / ред. 3. Морохоева / DEBATY ARTES LIBERALES. T. VI. Warszawa : Instytut Badań Interdyscyplinarnych «Artes Liberales», Uniwersytet Warszawski. 312 c. С. 279-293.

Ламажаa, Ч. К. (2015) Социология молодежи Тувы // Знание. Понимание. Умение. № 3. С. 340-348. DOI: https:// www.doi.org/10.17805/zpu.2015.3.30

Ламажаа, Ч. К. (2018) Национальный характер тувинцев. М. ; СПб. : Нестор-История. 240 с.

Ламажаа, Ч. К. (2019) Геокультурные образы буддийского мира тувинцев: исторический контекст и современность // Новые исследования Тувы. № 3. С. 27-40. DOI: https://www.doi.org/10.25178/nit.2019.3.3

Ламажаa, Ч. К. (2021) Тувинские обряды дагылга в XXI веке // Этнографическое обозрение. № 2. C. 125-143. DOI: https://doi.org/10.31857/S086954150014811-2

Ламажаа, Ч. К., Бичелдей, У. П., Монгуш, А. В. (2020) Тувинское буддийское паломничество: от традиции к вере // Новые исследования Тувы. № 4. C. 135-155. DOI: www.doi.org/10.25178/nit.2020.4.10

Ламажаа, Ч. К., Бичелдей, У.П. (2021) Основные характеристики тувинского буддийского паломничества рубежа XIX-XX веков // Новые исследования Тувы. № 2. C. 6-17. DOI: https:/www.doi.org/10.25178/nit.2021.2.1

Михалев, М. С. (2018) Российско-китайское трансграничье: этносоциальные аспекты // Проблемы Дальнего Востока. № 6. С. 123-134. DOI: https://www.doi.org/10.31857/S013128120002696-6

Монгольский мир между Востоком и Западом (2014) / отв. ред. Ю. В. Попков, Ж. Амарсанаа. Новосибирск, Автограф. 351 с.

Монгуш, Д. А. (1967) Развитие тувинского языка в советскую эпоху // Ученые записки. Вып. XII / отв. ред. Н. А. Сердобов. Кызыл : Тувинское книжное издательство. 281 с. С. 96-107.

Монгуш, М. В. (2001) История буддизма в Туве (вторая половина VI - конец XX в.). Новосибирск : Наука. 200 с.

Монгуш, М. В. (2010) Один народ: три судьбы. Тувинцы России, Монголии и Китая в сравнительном контексте. Осака : Национальный музей этнологии. 369 с.

Монгуш, М. В. (2012) Деятельность нетрадиционных конфессий в Туве: 1990-2010 гг. // Новые исследования Тувы. № 1. С. 58-70. 
Монгуш, М. В. (2015) Христианские общины Тувы: краткий очерк // Мировоззрение населения Южной Сибири и Центральной Азии в исторической ретроспективе. № 8. С. 159-175.

Монгуш, М. В. (2016) Традиционный и западный буддизм в современной России : опыт сравнительного анализа // Новые исследования Тувы. № 1. С. 5-19.

Насибова, А. С. (2015) Эволюция идей пантюркизма во внешней политике Турецкой республики // Современные евразийские исследования. № 3. С. 113-118.

Ойдуп, Т. М., Кылгыдай А.-К. Ч. (2012) Особенности межэтнических связей населения тувинско-монгольского приграничья // Социологические исследования. № 6. С. 136-140.

Отрощенко, И. В. (2015) Языковая политика и культурное строительство в Тувинской Народной Республике // Новые исследования Тувы. № 2. С. 16-31.

Пограничье культур - культуры пограничья (2012) / ред. 3. Морохоева / DEBATY ARTES LIBERALES. T. VI. Warszawa : Instytut Badań Interdyscyplinarnych «Artes Liberales», Uniwersytet Warszawski. 312 c.

Попков, Ю. В., Тюгашев, Е. А. (2019) Пространственный образ Тувы в объективе социокультурной феноменологии // Новые исследования Тувы. № 3. С. 4-14. DOI: https://www.doi.org/10.25178/nit.2019.3.1

Проблемы истории и культуры кочевых цивилизаций Центральной Азии. Т. II. История. Философия. Социология. Культурология и искусство (2000): Материалы международной научной конференции. Улан-Удэ : Изд-во БНЦ СО РАН. 375 c.

Родевич, Вс. (1910) Очерки Урянхайского края (Монгольского бассейна реки Енисея). СПб. : Типография Министерства путей сообщения. 230 с.

Самдан, А. А. (2001) Монголоязычные источники по истории Тувы: дис. ... канд. ист. наук. М. 151 с.

Сат, Ш. Ч. (1973) Формирование и развитие тувинского национального литературного языка. Кызыл : Тувинское книжное издательство. 193 с.

Сат, Ш. Ч. (1996) Тувинский язык // Языки мира: Тюркские языки / отв. ред. Э. Р. Тенишев. М. : ИД «Кыргызстан». 545 с. С. $384-393$.

Серээдар, Н. Ч. (2018) Тувинский язык как средство общения тувинцев: проблемы и перспективы // Новые исследования Тувы. № 1. С. 4-19. DOI: https://www.doi.org/10.25178/nit.2018.1.1

Терентьев, А. (2014) Буддизм в России - царской и советской. СПб. : Издание А. Терентьева. 484 с.

Тундума, Э. Э. (2019) Ассоциативная репрезентация гражданской и этнорегиональной идентичности жителей Республики Тыва // Мир науки, культуры, образования. № 1. С. 419-420.

Хантингтон, С. (1996) Столкновение цивилизаций. М. : АСТ. 660 с.

Хатунцев, С. В. (2011) Лимитрофы - межцивилизационные пространства Старого и Нового Света // Полис. № 2. C. 86-98.

Хертек, Л. К. (2016) Тувинско-монгольские связи и отношения в период Тувинской Народной Республики // Новые исследования Тувы. № 3. С. 65-81.

Хомушку, О. М. (2000) К характеристике религиозной ситуации в Республике Тыва // Государство, религия, церковь в России и за рубежом. № 3. С. 27-35.

Хомушку, О. М. (2005) Религия в культуре народов Саяно-Алтая. М. : РАГС. 225 с.

Цивилизационный выбор и пограничье (2011) / ред. Я. Кеневич / Debaty IBI AL. T. IV. Warszawa : Instytut Badań Interdyscyplinarnych «Artes Liberales», Uniwersytet Warszawski. 354 c.

Цыбенова, Ч. С. (2013) Современная языковая ситуация в Республике Тыва : автореф. дисс. ... канд. филол. н. М. 24 c.

Цыбенова, Ч. С. (2018) Функциональное развитие тувинского языка: диахронический аспект // Томский журнал ЛИНГ и АНТР. № 3 (21). С. 56-66.

Цыбенова, Ч. С. (2019) Социальная характеристика языковой ситуации в Республике Тыва // Oriental Studies. № 3. C. 460-477. DOI: https://doi.org/10.22162/2619-0990-2019-43-3-460-477

Цымбурский, В. Л. (2000) Россия - Земля за Великим Лимитрофом : цивилизация и ее геополитика. М. : Эдиториал УРСС. 144 с.

Leung, K. Z. (2017) Contemporary Youth Identity in the Republic of Tuva, Russia // Новые исследования Тувы. № 3. C. $49-65$. DOI: $10.25178 /$ nit.2017.3.3

Дата поступления: 16.06.2021 2.

\section{REFERENCES}

Avatkov, V. (2014) Neoosmanizm. Bazovaia ideologema i geostrategiia Turtsii [Neoosmanism. Basic ideology and geostrategy of the contemporary Turkey]. Svobodnaia mysl', no. 3, pp. 71-78. (In Russ.). 
Anaiban, Z. V., Guboglo, M. N. and Kozlov M. S. (1999) Formirovanie etnopoliticheskoi situatsii [Shaping the ethnopolitical situation]. Vol. 1. Ocherki istorii postsovetskoi Tuvy [Essays on the history of post-Soviet Tuva]. Moscow, TsIMO. 420 p. (In Russ.).

Anaiban, Z. V. and Tiukhteneva, S. P. (2008) Etnokul'turnaia adaptatsiia naseleniia Iuzhnoi Sibiri (sovremennyi period) [Ethnocultural adaptation of the population of Southern Siberia in the contemporary period]. Moscow, s. n. 217 p. (In Russ.).

Aref'ev, A. L., Bakhtikireeva, U. M. and Siniachkin, V. P. (2021) Problemy bilingvizma v sisteme shkol'nogo iazykovogo obrazovaniia Respubliki Tyva [Bilingualism in language education in secondary schools of the Republic of Tuva]. New Research of Tuva, no. 1, pp. 255-272. (In Russ.). DOI: https://www.doi.org/10.25178/nit.2021.1.14

Arnason, I. (2015) Ponimanie mezhtsivilizatsionnogo vzaimodeistviia [Understanding intercivilizational encounters]. Metod, no. 5, pp. 109-123. (In Russ.).

Bavuu-Surun, M. V. (2010) Tuvinskii iazyk na sovremennom etape: obrazovatel'nyi aspekt [Tuvan language on the contemporary stage: the educational aspect]. New Research of Tuva, no. 3, pp. 57-71. (In Russ.).

Badmaev, V. N., Ulanov, M. S., Lamazhaa, Ch. K., Bicheldei, U. P., Antonov, V. I. and Ochirova, O. A. (2020) Rossiia i buddiiskii mir glazami molodezhi Tuvy, Buriatii i Kalmykii (po materialam sotsiologicheskogo oprosa) [Russia and the Buddhist world through the eyes of the youth in Tuva, Buryatia and Kalmykia: a sociological survey and its outcomes]. New Research of Tuva, no. 1, pp. 35-49. (In Russ.). DOI: https://www.doi.org/10.25178/nit.2020.1.3

Berzin, A. (1992) Tibetskii buddizm: istoriia i perspektivy razvitiia [Tibetan Buddhism: History and prospects of development]. Volgograd, s. n. 32 p. (In Russ.).

Bicheldei, K. A. (2010) 80 let tuvinskoi pis'mennosti: stanovlenie, razvitie, perspektivy [The 80th anniversary of the Tuvan written language: formation, development, perspectives]. New Research of Tuva, no. 2, pp. 210-229. (In Russ.).

Borgoiakova, T. G. and Bitkeeva, A. N. (2020) Tuvinskii iazyk v pravovom i funktsional'nom izmerenii [Tuvan language in legal and functional aspect]. New Research of Tuva, no. 1, pp. 50-59. (In Russ.). DOI: https://www.doi.org/10.25178/ nit.2020.1.4

Buxhoeveden, A. O. (1902) Russkii Kitai : ocherki diplomaticheskikh snoshenii Rossii s Kitaem [Russian China: Essays on Russia's Diplomatic Relations with China]. Port-Artur : Izdanie knizhnogo sklada «Novyi krai». Part 1: Pekinskii dogovor : 1860 g. 239 p. (In Russ.).

Burovskii, A. M. (1995) Stepnaia skotovodcheskaia tsivilizatsiia: kriterii opisaniia, analiza i sopostavleniia [Pastoral civilization of the steppes: criteria for description, analysis and comparison]. In: Tsivilizatsii [Civilizations]. Vol. 3 / ed. by A. O. Chubar'ian. Moscow, Nauka. 239 p. Pp. 151-164. (In Russ.).

Garri, I. R. (2020) Buddizm i politika vo Vnutrennei Azii [Buddhism and Politics in Inner Asia]. Oriental Studies, vol. 13, no. 1, pp. 8-16. (In Russ.). DOI: https://www.doi.org/10.22162/2619-0990-2020-47-1-8-16

Gordievskii, A. (2007) Pantiurkizm bez Rossii [Pan-Turkism without Russia]. Rossiia i musul'manskii mir, no. 3, pp. 78-80. (In Russ.).

Vanchikova, Ts. P. (2019) Buddizm v Mongolii: istoriia, dukhovenstvo, monastyri [Buddhism in Mongolia: history, clergy, monasteries]. Irkutsk, Ottisk. 292 p. (In Russ.).

Dashkovskii, P. K., Shershneva, E. A., Bicheldei, U. P. and Mongush, A. V. (2021) Religioznaia situatsiia v Respublike Tyva (po rezul'tatam sotsiologicheskogo issledovaniia) [Religious Situation in the Republic of Tuva (Based on the Results of a Sociological Study)]. New Research of Tuva, no. 2, pp. 18-34. (In Russ.). DOI: https://www.doi.org/10.25178/nit.2021.2.2

Datsyshen, V. G. (2005) Saianskii rubezh. Iuzhnaia chast' Prieniseiskogo kraia i russko-tuvinskoe otnosheniia v 1616-1911 gg. [The Sayan frontier. The southern part of the Yenisei Region and Russian-Tuvan relations in 1616-1911] Tomsk, STT. 250 p. (In Russ.).

Dorzhu, Z. Yu. (2019) Mezhetnicheskoe vzaimodeistvie russkikh i tuvintsev v sovetskoi i postsovetskoi Tuve (na primere natsional'no-smeshannykh semei) [Interethnic exchange of Russian and Tuvans in Soviet and Post-Soviet Tuva: the case of ethnically mixed families]. New Research of Tuva, no. 1, pp. 144-156. (In Russ.). DOI: https://www.doi.org/10.25178/ nit.2019.1.11

Zhelezniakov, A. S. (2016) Mongol'skaia tsivilizatsiia. Istoriia i sovremennost'. Teoreticheskoe obosnovaniia atlasa [Mongolian civilization: History and modernity: A theoretical background for the Atlas]. Moscow, Ves' mir. 288 p. (In Russ.).

Za tri veka. Tuvinsko-russkie-mongol'skie-kitaiskie otnosheniia (1616-1915 gg.) [For three centuries. Tuva-RussianMongolian-Chinese relations (1616-1915)] (1995): collection of archival documents / comp. by V. A. Dubrovskii. Kyzyl, s. n. 84 p. (In Russ.).

Zamyatina, N. Yu. (2006) Goroda, raiony i strany v politicheskom rel'efe rossiiskikh regionov. Po materialam ofitsial'nykh saitov sub'ektov RF [Cities, areas and countries in the political landscape of Russian Regions: from official; sites of the constituent subjects of the Russian Federation]. Polis. Political Studies, no. 2, pp. 122-138. (In Russ.). DOI: https://www. doi.org/10.17976/jpps/2006.02.10

Ivanova, V. V. (2012) Speloe iabloko. Idealy pantiurkizma i identifikatsionnyi sinkretizm [A ripe apple: The ideals of pan-Turkism and identification syncretism]. Aziia i Afrika segodnia, no. 1, pp. 65-71. (In Russ.). 
Istoriia Tuvy [The History Of Tuva] (2001) : in 2 vol. $2^{\text {nd }}$ ed / ed. by S. I. Vanshtein and M. Kh. Mannai-ool. Novosibirsk, Nauka. Vol. I. 367 p. (In Russ.).

Kireev, A. A. (2012) K voprosu o tipologii aziatskikh granits Rossii (I chast') [On the question of the typology of the Asian borders of Russia: Part I]. Oikumena, no. 4, pp. 37-46. (In Russ.).

Kirichenko, O. V. (2010) Rossiiskoe tsivilizatsionnoe pogranich'e [The Russian civilizational frontier]. Traditsii $i$ sovremennost', no. 10, pp. 34-74. (In Russ.).

Kradin, N. N. (1995) Kochevnichestvo v tsivilizatsionnom i formatsionnom razvitii [Nomadism in civilizational and formational development]. In: Tsivilizatsii [Civilizations]. Vol. 3 / ed. by A. O. Chubar’ian. Moscow, Nauka. 239 p. Pp. $164-$ 179. (In Russ.).

Kradin, N. N. (2020) Kochevniki i vsemirnaia istoriia [Nomads and world history]. St. Petersburg, Oleg Abyshko Publ. 416 p. (In Russ.).

Kuz'min, S. L. (2018) Uriankhaiskii vopros i mongolo-tuvinskie otnosheniia v nachale XX v. [The Uriankhai question and Mongol-Tuvan relations in the early twentieth century]. Oriental studies, vol. 37, issue 3, pp. 2-14. (In Russ.).

Kul'pin-Gubaidullin, E. S. (2008) Spor o tsivilizatsii [The dispute about civilization]. Zolotoordynskaia tsivilizatsiia, no. 1, pp. 7-13. (In Russ.).

Lamazhaa, Ch. K. (2012) Kontsepty «Za Saianami» i «tuvinskoe vremia»v obshchestvennom diskurse Tuvy [The concepts of "Beyond the Sayans" and "Tuvan time" in the public discourse of Tuva]. In: Pogranich'e kul'tur - kul'tury pogranich'ia [Borderlands of cultures - cultures of the borderlands] / ed. by Z. Morokhoeva / DEBATY ARTES LIBERALES. T. VI. Warszawa, Instytut Badań Interdyscyplinarnych «Artes Liberales», Uniwersytet Warszawski. 312 p. Pp. 279-293. (In Russ.).

Lamazhaa, Ch. K. (2015) Sotsiologiia molodezhi Tuvy [Sociology of youth in Tuva]. Znanie. Ponimanie. Umenie, no. 3, pp. 340-348. (In Russ.). DOI: https://www.doi.org/10.17805/zpu.2015.3.30

Lamazhaa, Ch. K. (2018) Natsional'nyi kharakter tuvintsev [National character of Tuvans]. Moscow, St. Petersburg, Nestor-Istoriia. 240 p. (In Russ.)

Lamazhaa, Ch. K. (2019) Geokul'turnye obrazy buddiiskogo mira tuvintsev: istoricheskii kontekst i sovremennost' [Geocultural images of the Tuvan Buddhist world: historical context and modernity]. New Research of Tuva, no. 3, pp. 2740. (In Russ.). DOI: https://www.doi.org/10.25178/nit.2019.3.3

Lamazhaa, Ch. K. (2021) Tuvinskie obriady dagylga v XXI veke [Dagylga rites in 20th century Tuva]. Etnograficheskoe obozrenie, no. 2, pp. 125-143. (In Russ.). DOI: https://doi.org/10.31857/S086954150014811-2

Lamazhaa, Ch. K., Bicheldei, U. P. and Mongush, A. V. (2020) Tuvinskoe buddiiskoe palomnichestvo: ot traditsii k vere [Tuvan Buddhist pilgrimage: from tradition to faith]. New Research of Tuva, no. 4, pp. 135-155. (In Russ.). DOI: www.doi. org/10.25178/nit.2020.4.10

Lamazhaa, Ch. K. and Bicheldei, U. P. (2021) Osnovnye kharakteristiki tuvinskogo buddiiskogo palomnichestva rubezha XIX-XX vekov [The main characteristics of Tuvan Buddhist pilgrimage at the turn of the 20th century]. New Research of Tuva, no. 2, pp. 6-17. (In Russ.). DOI: https://www.doi.org/10.25178/nit.2021.2.1

Mikhalev, M. S. (2018) Rossiisko-kitaiskoe transgranich'e: etnosotsial'nye aspekty [Russia-China transborder area: ethno-social aspects]. Far Eastern Studies, no. 6, pp. 123-134. (In Russ.). DOI: https://www.doi.org/10.31857/ S013128120002696-6

Mongol'skii mir mezhdu Vostokom i Zapadom [The Mongolian world between East and West] (2014) / ed. by Yu. V. Popkov and Zh. Amarsanaa. Novosibirsk, Avtograf. 351 p. (In Russ.).

Mongush, D. A. (1967) Razvitie tuvinskogo iazyka v sovetskuiu epokhu [The development of the Tuvan language in the Soviet era]. In: Uchenye zapiski, vol. XII / ed. by N. A. Serdobov. Kyzyl, Tuva Book Publishing House. 281 p. Pp. 96-107. (In Russ.).

Mongush, M. V. (2001) Istoriya buddizma v Tuve (vtoraya polovina VI - konets XX v.) [The History of Buddhism in Tuva (latter half of the 6th - late 20th cc.)]. Novosibirsk, Nauka. 200 p. (In Russ.).

Mongush, M. V. (2010) Odin narod: tri sud'by. Tuvintsy Rossii, Mongolii i Kitaia v sravnitel'nom kontekste [One people, three destinies. Tuvans of Russia, Mongolia and China in a comparative context]. Osaka, Natsional'nyi muzei etnologii. 358 p. (In Russ.).

Mongush, M. V. (2012) Deiatel'nost' netraditsionnykh konfessii v Tuve: 1990-2010 gg. [Activities of non-traditional religions in Tuva]. New Research of Tuva, no. 1, pp. 58-70. (In Russ.).

Mongush, M. V. (2015) Khristianskie obshchiny Tuvy: kratkii ocherk [Christian communities of Tuva: A short sketch]. Mirovozzrenie naseleniia Iuzhnoi Sibiri i Tsentral'noi Azii v istoricheskoi retrospektive, no. 8, pp. 159-175. (In Russ.).

Mongush, M.V. (2016) Traditsionnyi i zapadnyi buddizm v sovremennoi Rossii: opyt sravnitel'nogo analiza [Traditional and Western Buddhism in Russia: A comparative study]. New Research of Tuva, no. 1, pp. 5-19. (In Russ.).

Nasibova, A. S. (2015) Evoliutsiia idei pantiurkizma vo vneshnei politike Turetskoi respubliki [The evolution of the pan-Turkist ideas in the foreign policy of the Republic of Turkey]. Sovremennye evraziiskie issledovaniia, no. 3, pp. 113-118. 
(In Russ.).

Oidup, T. M. and Kylgydai A.-K. Ch. (2012) Osobennosti mezhetnicheskikh sviazei naseleniia tuvinsko-mongol'skogo prigranich'ia [Interethnic relations among the population of the Tuvan-Mongolian border region]. Sotsiologicheskie issledovaniia, no. 6, pp. 136-140. (In Russ.).

Otroshchenko, I. V. (2015) Iazykovaia politika i kul'turnoe stroitel'stvo v Tuvikskoi Narodnoi Respublike [The language policy and cultural building in the Tuvan People's Republic]. New Research of Tuva, no. 2, pp. 16-31. (In Russ.).

Pogranich'e kul'tur - kul'tury pogranich'ia [Borderlands of cultures - cultures of the borderlands] (2012) / ed. by Z. Morokhoeva / DEBATY ARTES LIBERALES. T. VI. Warszawa, Instytut Badań Interdyscyplinarnych «Artes Liberales», Uniwersytet Warszawski. 312 p. (In Russ.).

Popkov, Yu. V. and Tyugashev, E. A. (2019) Prostranstvennyi obraz Tuvy v ob'ektive sotsiokul'turnoi fenomenologii [The spatial image of Tuva in the focus of sociocultural phenomenology]. New Research of Tuva, no. 3, pp. 4-14. (In Russ.). DOI: https://www.doi.org/10.25178/nit.2019.3.1

Problemy istorii i kul'tury kochevykh tsivilizatsii Tsentral'noi Azii [Problems of history and culture of nomadic civilizations of Central Asia] (2000). Vol. II. History. Philosophy. Sociology. Cultural Studies and Art (2000): Materials of the international scientific Conference. Ulan-Ude, BNTs SO RAN Publ. 375 p. (In Russ.).

Samdan, A. A. (2001) Mongoloiazychnye istochniki po istorii Tuvy [Mongolian language sources on the history of Tuva]: Diss.... Candidate of History. Moscow. 151 p. (In Russ.).

Sat, Sh. Ch. (1973) Formirovanie i razvitie tuvinskogo natsional'nogo literaturnogo iazyka [The rise and development of the Tuvan literary language]. Kyzyl, Tuva Book Publishing House. 193 p. (In Russ.).

Sat, Sh. Ch. (1996) Tuvinskii iazyk [Tuvan language]. In: Iazyki mira: Tiurkskie iazyki [Languages of the world: Turkic languages] / ed. by E. R. Tenishev. Moscow, ID «Kyrgyzstan». 545 p. Pp. 384-393. (In Russ.).

Sereedar, N. Ch. (2018) Tuvinskii iazyk kak sredstvo obshcheniia tuvintsev: problemy i perspektivy [Tuvan language as means of communication among Tuvans: Problems and prospects]. New Research of Tuva, no. 1, pp. 4-19. (In Russ.). DOI: https://www.doi.org/10.25178/nit.2018.1.1

Terent'ev, A. (2014) Buddizm v Rossii - tsarskoi i sovetskoi [Buddhism in Tsarist and Soviet Russia]. St. Petersburg, A. Terent'ev Publ. 484 p. (In Russ.).

Tunduma, E. E. (2019) Assotsiativnaia reprezentatsiia grazhdanskoi i etnoregional'noi identichnosti zhitelei Respubliki Tyva [Associative representation of the civil and ethno-regional identity of the inhabitants of the Republic of Tyva]. Mir nauki, kul'tury, obrazovaniia, no. 1, pp. 419-420. (In Russ.). Russ.).

Huntington, S. (1996) Stolknovenie tsivilizatsii [The clash of civilizations]. Transl. from Engl. Moscow, AST. 660 p. (In

Khatuntsev, S. V. (2011) Limitrofy - mezhtsivilizatsionnye prostranstva Starogo i Novogo Sveta [Limitrophes as intercivilizational spaces of the Old and New World]. Polis, no. 2, pp. 86-98. (In Russ.).

Khertek, L. K. (2016) Tuvinsko-mongol'skie sviazi i otnosheniia v period Tuvinskoi Narodnoi Respubliki [TuvanMongolian relations and links under the People's Republic of Tuva]. New Research of Tuva, no. 3, pp. 65-81. (In Russ.).

Khomushku, O. M. (2000) K kharakteristike religioznoi situatsii v Respublike Tyva [On the religious situation in the Republic of Tyva]. Gosudarstvo, religiia, tserkov'v Rossii i za rubezhom, no. 3, pp. 27-35. (In Russ.).

Khomushku, O. M. (2005) Religiia $v$ kul'ture narodov Saiano-Altaia [Religion in the culture of the Sayano-Altai peoples]. Moscow, RAGS. 225 p. (In Russ.).

Tsivilizatsionnyi vybor i pogranich'e [Civilizational choice and the Frontier] (2011) / ed. by Ya. Kenevich / Debaty IBI AL. T. IV. Warszawa, Instytut Badań Interdyscyplinarnych «Artes Liberales», Uniwersytet Warszawski. 354 p. (In Russ.).

Tsybenova, Ch. S. (2013) Sovremennaia iazykovaia situatsiia v Respublike Tyva : sotsiopsikholingvisticheskii aspekt [The contemporary linguistic situation in the Republic of Tyva: The socio- and psycholinguistic aspect] : Abstract of Diss.... Candidate of Philology. Ulan-Ude. 24 p. (In Russ.).

Tsybenova, Ch. S. (2018) Funktsional'noe razvitie tuvinskogo iazyka: diakhronicheskii aspekt [Functional development of the Tuvan language: The diachronic aspect]. Tomsk Journal LING \& ANTHRO, no. 3 (21), pp. 56-66. (In Russ.).

Tsybenova, Ch. S. (2019) Sotsial'naia kharakteristika iazykovoi situatsii v Respublike Tyva [The linguistic situation in the Republic of Tuva: Social characteristics]. Oriental Studies, no. 3, pp. 460-477. (In Russ.). DOI: https://doi. org/10.22162/2619-0990-2019-43-3-460-477

Tsymburskii, V. L. (2000) Rossiia - Zemlia za Velikim Limitrofom : tsivilizatsiia i ee geopolitika [Russia - The Land beyond the Great Limitrophe: Civilization and its Geopolitics]. Moscow, Editorial URSS. 144 p. (In Russ.).

Leung, K. Z. (2017) Contemporary Youth Identity in the Republic of Tuva, Russia. New Research of Tuva, no. 3, pp. 49-65. DOI: https://doi.org/10.25178/nit.2017.3.3 